\title{
Environment and foreign aid
}

\section{The well-known jibe that environmental protection is a self-indulgence of the rich is particularly apposite on the international plane. But the corollary is more foreign aid.}

Curious transformations are being effected in the environmental movement. That is one reading of the elections last weekend in the West German state of Hesse, where the environmental party which likes to be known as the Greens failed to repeat its successes of recent years and, unexpectedly, a coalition of the Christian Democrats and the Free Democrats is likely to form the next government. Does that mean that environmentalism is dead? Or is it merely that the environment now belongs to the middle classes?

There seems no question that it is the well-to-do who call the shots in the protection of the environment. They, after all, are those who have risen above the struggle for survival to a state in which they can regard smokestacks as an offence against nature and not a sign that there are jobs to be had, or regard tigers with affection and not fear. But how can it then be possible to make environmental policies for the world as a whole, given its diversity? This was the underlying but mostly unspoken theme of a Ditchley (north of Oxford) conference two weeks ago. In the protection of the environment, whose interests are at stake, those of the poor or of the rich?

There is a great deal in the belief that what would be generally considered as a proper concern for the natural environment is largely a function of prosperity. Only in the very richest countries, Japan and the United States (in some order), does one ever see people walking in the open with cotton gauze across their mouths in the belief that breathing unfiltered air will otherwise kill them. There are many other poorer parts of the world, Timbuctoo or London (England), where the same danger is more immediate. The general rule seems to be that a proper concern for the environment is being recognized for what it always has been, a kind of luxury.

That is not all that remarkable, as modest reflection will confirm. Not merely is there some kind of empirical correlation between gross national product per capita and national consciousness of environmental protection (in a sense, to be sure, that needs to be defined), but the same principle appears to apply at the level of the small group and even of the individual. Who but the well-to-do have the leisure, the surplus energy and the letter-writing capability to rise up in the defence of endangered species, landscapes or buildings?
Nor should the habitual defence of the natural environment predominantly by the wealthy, national or individual, be the occasion for ridicule and scorn. On the contrary, as the past few centuries of European history have vividly shown, the traditions of European art now widely revered were fostered and kept alive by the indulgence of the rich. Is Rembrandt the less to be respected because his customers were necessarily substantial people?

The flaw in this defence of the patronage of art (and even of mediaeval science) by those well-off enough to be able to match their luxuries to their tastes is that it is also a licence for fickle sponsorship. Wits say that the decision of the US Central Intelligence Agency to found Encounter magazine (which it did, although the two organizations have since parted company) shows how great things can stem from squalid motives; unhappily, the agency was probably up to other tricks at the same time. And the maxim that the rich know best, or that the market will decide, is generally distrusted where the natural environment is in question. The economists' explanation is that market preferences do not add up to a representation of the public good.

Some issues are nevertheless a considerable challenge to the notion that environmental protection is a self-evidently prudent policy for everybody. Take, for example, the species of whales still extant but much diminished in number. Like people, they sit at the top of elaborate food-chains which are largely separate from each other. The armchair ecologists' dictum that everything hangs together notwithstanding, it is hard to see what ecological harm would come to people if whales were promptly extinguished. This, apparently, is what the Icelandic, Japanese and Soviet members of the International Whaling Commission believe. Their more philosophical opponents on whaling rightly take the view that it would be a global tragedy if it were never again possible to go to sea in the hope of seeing one of these great creatures break the water. But that, of course, is a kind of luxury.

The more immediate issue is that of the tropical rain-forests, of which most of those who are able to purchase popular magazines have heard. There is a possibility that the steady destruction of these huge reservoirs of carbon will add to the greenhouse problem. Certainly, there is a high chance that, once removed, the soil beneath will quickly erode. People are probably also on sure ground in saying that, in and beneath these dense canopies, there are probably uncounted species whose genetic constitution would be of great value at some point in the future. The case for not destroying the world's tropical forests, while not quite as powerful as that for not staging nuclear warfare, is very strong. So why the difficulty?

Most tropical forests have survived the past century because they are where the indigenous populations are so poor that they have until recently lacked the means to cut down the trees. And that is not a remarkable coincidence: rain-forests may be splendid ways of supporting a diversity of species but, left alone, they are not particularly hospitable to people. That may be why the rain-forest now most threatened, that of the Amazon, is within the territory of the largest but still, in per capita terms, the poorest of the developing countries. How can it hope to pay off its debts to the Western banks if it cannot sell a few cubic kilometres of irreplaceable hardwood for what the market will yield?

This, and in many other places, is where the contradictions of environmental protection arise most sharply. The most serious of those who would protect the environment, who make great sacrifices in their own lives to avoid damage to some special natural phenomenon, are prone to issue prescriptions that others should do likewise. Within national frontiers, the issue can be settled by the democratic process. Across frontiers, there is no means but rhetoric by which the rich can persuade the poor to do the decent thing.

Or not quite. The logic of international environmental protection and conservation is that, if it is the rich who want to keep things as they are, and the poor who need to change them for the sake of survival, the rich should compensate the poor for their restraint. In short, there is no basis for international policies on environmental protection that do not begin from the assumption that the policy-objectives are luxuries, are not to be scorned on that account and that their accomplishment requires a welding together of policies on environmental protection and foreign aid that has not so far been attempted. Unfortunately, to tell from the international rhetoric of the environment, the rich have calculated that exhortation will be cheaper. John Maddox 